\title{
ENGLISH GAMES UNTUK MENINGKATKAN SPEAKING SKILL DAN MOTIVASI SISWA KELAS $X$ SMK
}

\author{
Nurbadri
}

SMKN 2 Kota Sawahlunto

\begin{abstract}
Teaching speaking should be oriented to the vocational purpose at SMK. In reality, many students get problem to speak English and get low learning motivation. This makes them unsuccessful to get the proper jobs. The purpose of this research was to test whether the game can improve students' speaking skill and their learning motivation at grade one of SMK Negeri 2 Sawahlunto and to find out factors influence the improvement the speaking skill and learning motivation. This research is classified into classroom action research. Data were collected through assessment, observation, and interview. The assessment was used for assessing the speaking; the observation sheet was used for assessing students' learning motivation and then interview and field note were used for having the further information. The findings of this research have answered the research questions, that the using English game can improve students' speaking skill and learning motivation at SMKN 2 Sawahlunto. This technique is very useful to improve students' speaking skill and learning motivation. This technique must be applied at SMKN 2 Sawahlunto, and it is suggested that school with poor speaking skill and low learning motivation to apply and develop this method to overcome their learning English problem.
\end{abstract}

Keyword: learning motivation, speaking skill, English subject

(1) This is an open access article distributed under the Creative Commons Attribution License, which permits unrestricted use, distribution, and reproduction in any medium, provided the original work is properly cited. C2017 by author and IICET.

\section{PENDAHULUAN}

Proses pengajaran dan pembelajaran di sekolah menengah kejuruan dimaksudkan untuk tujuan yang khusus, yaitu berorientasi kepada vokasi. Pembelajaran di sekolah menengah kejuruan harus menekankan pada praktik. Begitupun dengan pembelajaran Bahasa Inggris di sekolah kejuruan, harus menekankan pada praktik, seperti 
speaking skill. Pembelajaran harus bersifat student centered. Guru harus bisa mendorong siswa untuk mempraktikkan Bahasa Inggris ketimbang hanya sekedar mempelajarinya. Berdasarkan observasi awal di beberapa sekolah menengah kejuruan di kota Sawahlunto, diketahui pembelajaran Bahasa Inggris masih berorientasi pada guru. Pembelajaran tersebut masih berkutat pada teori seperti lafal pengucapan, kosa kata, grammar, dan sebagainya hingga siswa merasa kesulitan dalam belajar dan kesulitan dalam berbicara.

Kesulitan dalam pembelajaran Bahasa Inggris ini juga dialami oleh siswa kelas X SMKN 2 Sawahlunto, tempat dimana peneliti mengajar. Meskipun mayoritas siswa sudah mempelajari Bahasa Inggris semenjak bangku sekolah menengah pertama, siswa masih tidak bisa berbicara Bahasa Inggris. Siswa pada umumnya merasa segan atau malu berbicara Bahasa Inggris. Jika mereka didesak untuk bicara dalam Bahasa Inggris, mereka akan menggerutu dan menghindar. Hal ini disebabkan oleh beberapa faktor, di antaranya karena siswa belajar Bahasa Inggris hanya untuk memperoleh nilai yang bagus, rendahnya ketertarikan atau motivasi mereka, dan fasilitas belajar yang kurang memadai. Peneliti kemudian mencari informasi terkait strategi pembelajaran di Universitas Negeri Padang. Peneliti menemukan bahwa banyak terdapat strategi ataupun teknik bagus yang bisa meningkatkan speaking skill dan motivasi belajar siswa. Strategi dan teknik tersebut antar lain story telling, bermain peran, cerita bergambar, dan sebagainya. Peneliti merasa tertarik untuk menggunakan beberapa teknik ini untuk meningkatkan speaking skill dan motivasi belajar siswa kelas X SMKN 2 Sawahlunto.

Berbicara adalah kemampuan untuk mengekspresikan ide, pendapat, dan perasaan secara lisan. Hornby (1995 mengatakan bahwa berbicara adalah mengekspresikan sesuatu dalam bahasa tertentu.Jadi, dalam berbicara terdapat pengiriman ide dari seseorang ke orang lain yang mendengarkannya. Richards (2001) menyatakan bahwa seseorang sering mengalami kesulitan dalam berbicara bahasa asing tertentu. Untuk berbicara secara efektif, seseorang harus memiliki kemampuan berbicara. Kemampuan berbicara tidak hanya sekedar kemampuan verbal, melainkan juga kemampuan dalam mengatur intonasi, mimik wajah, gerak tubuh, nada suara, dan sebagainya. Menurut Brown (2004), untuk menguji kemampuan berbicara siswa, guru bisa melaksanakan wawancara, drama, diskusi, dan permainan. Peneliti kemudian memilih permainan (games) untuk menilai kemampuan bicara Bahasa Inggris siswa. Harris (1979) dan Brown (2004) menyatakan indikator kemampuan berbicara adalah: mampu mengekspresikan perasaan, ide, dan pendapat; mampu menggunakan kosa kata yang tepat, grammar yang benar, pemahaman menyeluruh, dan pelafalan yang benar serta lancar; mampu menyampaikan maksud dengan baik; mampu menunjukkan kepercayaan diri yang baik; dan mampu menggunakan susunan kalimat yang baik.

Belajar adalah aktivitas yang dilakukan oleh siswa untuk mencapai kebiasaan baru. Kesuksesan seseorang dalam belajar dipengaruhi oleh berbagai faktor, antara lain minat, kepercayaan diri, motivasi belajar, dan lain-lain. Motivasi dapat diartikan sebagai kesiapan seseorang untuk melakukan sebuah aktivitas. Prayitno (1989) menyatakan bahwa motivasi adalah jantungnya proses pembelajaran. Oleh karena itu, guru harus bisa membangkitkan motivasi belajar siswa. Selain untuk meningkatkan speaking skill, penelitian ini juga ditujukan untuk meningkatkan motivasi belajar siswa melalui pembelajaran yang menerapkan English Games. Ada banyak anfaat penggunaan games dalam pembelajaran bahas. Games mendorong siswa untuk membangun ketertarikan akan sesuatu. Kim (1995) menjelaskan ada enam manfaat penggunaan permainan dalam pembelajaran bahasa, yaitu: memotivasi, membantu siswa berusaha dalam belajar, menyediakan berbagai praktik bahasa dengan bermacam speaking, writing, listening, dan reading skill, mendorong siswa untuk berinteraksi dan berkomunikasi, dan menciptakan penggunaan bahasa yang bermakna. Permainan juga dapat menurunkan tingkat kecemasan siswa. Peneliti menciptakan proses pembelajaran yang bisa memotivasi siswa untuk belajar dengan penerapan games yang juga membantu meningkatkan speaking skill siswa. Permainan yang digunakan berupa kartu, puzzle, dan tebak-tebakan. Aktivitas belajar yang dilakukan berupa praktik pelafalan kata dan conversation.

\section{METODE}

Penelitian ini merupakan penelitian tindakan kelas (classroom action research). Penelitian tindakan kelas merupakan penelitian yang ditujukan untuk meningkatkan kualitas pembelaran di kelas. Penelitian tindakan kelas terdiri dari empat tahapan yang meliputi perencanaan, pelaksanaan, pengamatan, dan refleksi. Penelitian ini dilakukan dalam tiga siklus, dimana setiap siklus terdiri dari empat tahapan yang telah disebutkan sebelumnya.

Penelitian ini dilaksanakan di SMKN 2 Kota Sawahlunto, tempat peneliti mengajar. Populasi adalah siswa kelas X SMKN 2 Kota Sawahlunto. Peneliti melibatkan guru Bahasa Inggris lain sebagai pengamat atau observer. 
Pengumpulan data dilakukan denganmenggunakan dua instrumen. Pertama, instrumen tes speaking untuk memperoleh data speaking skill siswa. Kedua, instrumen observasi untuk memperoleh data tentang motivasi belajar siswa. Terdapat lima indikator yang dimuat dalam tes speaking skill, yaitu utterance, fluency, structure, vocabulary, dan understanding. Sedangkan untuk instrumen observasi, terdapat empat indikator yang meliputi bekerja, keingintahuan, minat, dan kompetisi. Skor ideal yang digunakan dalam tes adalah 4 .

\section{HASIL DAN PEMBAHASAN}

Penelitian ini terdiri dari tiga siklus yang dilakukan dalam sembilan kali pertemuan. Setiap siklus terdiri dari empat tahap yang meliputi tahap perencanaan, pelaksanaan, pengamatan, dan refleksi.

\section{Siklus 1}

Peneliti bersama rekannya yang berperan sebagai pengamat melakukan pengamatan awal sebagai bahan untuk menyusun perencanaan. Hasil dari pengamatan terhadap speaking skill siswa diperoleh skor untuk utterance adalah 1,4; skor untuk fluency adalah 1,3; skor untuk structure adalah 1,3; dan skor untuk understanding adalah 1,3. Sedangkan hasil pengamatan terhadap motivasi belajar siswa diperoleh skor untuk working adalah 2,2; skor untuk competition 2,2; skor untuk curiousity adalah 2, 1; dan skor untuk mood adalah 2,1.

Berdasarkan hasil pengamatan, kemudian disusunlah perencanaan tindakan. Siklus 1 dilaksanakan dalam enam kali pertemuan. Dalam implementasi atau pelaksanaan tindakan, guru menggunakan enam macam English Games, yaitu guess the job, guess the mime, I spy, describe it, yesterday afternoon, dan have you cleaned the board?. Berikut ini adalah tabel yang menunjukkan perkembangan kemampuan berbicara siswa selama enam kali pertemuan.

Tabel 1 Speaking Skill Siswa pada Siklus 1

\begin{tabular}{cccccc}
\hline \multirow{2}{*}{ Pertemuan } & \multicolumn{5}{c}{ Skor Rata-rata Indikator } \\
\cline { 2 - 6 } $\mathbf{1}$ & Utterance & Fluency & Structure & Vocabulary & Understanding \\
$\mathbf{2}$ & 1,4 & 1,3 & 1,3 & 1,4 & 1,3 \\
$\mathbf{3}$ & 1,5 & 1,3 & 1,4 & 1,5 & 1,3 \\
$\mathbf{4}$ & 1,8 & 1,9 & 2,0 & 2,1 & 2,2 \\
$\mathbf{5}$ & 1,9 & 1,8 & 2,1 & 2,1 & 2,3 \\
$\mathbf{6}$ & 2,5 & 2,7 & 2,8 & 2,8 & 2,9 \\
\hline
\end{tabular}

Peneliti dan observer juga mengamati motivasi belajar siswa. Untuk mengamati motivasi belajar siswa, peneliti dan pengamat merujuk pada indikator working, competition,curiosity,danmood. Masing-masing indikator ini memperoleh skor sebagai berikut: working 2,7, competition 2,7, curiosity 2,7, dan mood 2,6.

Peneliti dan pengamat kemudian mendiskusikan dua hal, yaitu tentang speaking skill dan motivasi belajar siswa. Skor capaian siswa untuk dua hal ini masih rendah dan belum memuaskan. Hal ini disebabkan karakter siswa yang masih malu-malu, belum belajar dengan serius, dan gaya belajar yang masih lamban. Oleh karena skor yang diperoleh masih belum memuaskan, maka tindakan dilanjutkan ke siklus 2.

\section{Siklus 2}

Berdasarkan data yang diperoleh dari siklus 1, peneliti bersama observer kemudian merencanakan siklus 2 yang dilaksanakan juga dalam enam kali pertemuan. Dalam siklus 2, ada enam games yang direncanakan, yaitu if 
I go to, crisis, desert island game, famous people, shall I? and would you?, dan moment in history. Berikut ini adalah tabel yang menunjukkan perkembangan speaking skill siswa dalam siklus 2.

Tabel 2 Speaking Skill Siswa pada Siklus 2

\begin{tabular}{cccccc}
\hline \multirow{2}{*}{ Pertemuan } & \multicolumn{5}{c}{ Skor Rata-rata Indikator } \\
\cline { 2 - 6 } $\mathbf{1}$ & Utterance & Fluency & Structure & Vocabulary & Understanding \\
$\mathbf{2}$ & 2,3 & 2,3 & 2,1 & 2,1 & 2,1 \\
$\mathbf{3}$ & 2,1 & 2,1 & 2,0 & 2,5 & 2,3 \\
$\mathbf{4}$ & 2,7 & 2,8 & 2,7 & 2,7 & 2,7 \\
$\mathbf{5}$ & 2,7 & 2,7 & 2,5 & 2,8 & 2,8 \\
$\mathbf{6}$ & 2,7 & 2,8 & 2,7 & 2,7 & 2,7 \\
& 2,3 & 2,3 & 2,1 & 2,1 & 2,1 \\
\hline
\end{tabular}

Dari tabel di atas terlihat bahwa siswa mengalami kemajuan speaking skill dalam siklus 2 bila dibandingkan dengan siklus 1 . Skor rata-rata motivasi belajar siswa pun juga naik dibandingkan dengan siklus 1 dengan skor berturut-turut untuk working, competition, curiosity dan mood adalah 3,2, 3,2, 3,1, dan 3,2. Perkembangan siswa, baik kemampuan berbicara maupun motivasi belajar sudah meningkat dengan baik. Hanya saja pencapaian siswa masih belum memuaskan, khususnya untuk kemampuan berbicaranya. Oleh karena itu, tindakan dilanjutkan ke siklus 3.

\section{Siklus 3}

Data yang diperoleh dari siklus 2 menunjukkan bahwa sudah ada peningkatan terhadap kemampuan berbicara dan motivasi belajar siswa. Khusus untuk motivasi belajar siswa, peneliti dan pengamat menganggap sudah tidak ada lagi kendala yang berarti. Oleh karena itu, pada siklus 3 ini peneliti dan pengamat fokus pada peningkatan speaking skill siswa tanpa mengabaikan motivasi belajar siswa tentunya. Peneliti kembali menyusun berbagai games, yaitu guess where?, whose isthis?, adjective match, Aunt Betty's cat, big eaters, dan pluraltennis.Siklus 3 ini terdiri atas lima kali pertemuan. Berikut adalah tabel yang menunjukkan perkembangan kemampuan berbicara siswa selama siklus 3 .

Tabel 3 Speaking Skill Siswa pada Siklus 3

\begin{tabular}{cccccc}
\hline Pertemuan & \multicolumn{5}{c}{ Skor Rata-rata Indikator } \\
\cline { 2 - 6 } & Utterance & Fluency & Structure & Vocabulary & Understanding \\
$\mathbf{2}$ & 2,5 & 2,4 & 2,7 & 2,6 & 2,7 \\
$\mathbf{3}$ & 2,5 & 2,7 & 2,8 & 2,7 & 2,9 \\
$\mathbf{4}$ & 3,2 & 3,1 & 3,0 & 3,0 & 3,2 \\
$\mathbf{5}$ & 3,1 & 3,4 & 3,5 & 3,4 & 3,6 \\
& 3,5 & 3,4 & 3,4 & 3,4 & 3,5 \\
\hline
\end{tabular}

Dari tabel di atas dapat dilihat bahwa perkembangan speaking skill siswa semakin pesat dan memuaskan. Skor rata-rata motivasi belajar siswa pun juga naik dibandingkan dengan siklus 2 dengan skor berturut-turut untuk working, competition, curiosity dan mood adalah 3,5, 3,5, 3,4, dan 3,4. Oleh karena skor rata-rata yang diperoleh siswa, baik untuk speaking skill maupun motivasi belajar sudah meningkat dengan memuaskan, maka penelitian tindakan kelas ini dihentikan hingga siklus 3 saja. 


\section{Pembahasan}

\section{Speaking Skill}

Kemampuan berbicara siswa dapat ditingkatkan melalui beberapa strategi atau metode, dan salah satunya adalah melalui permainan bahasa (language games). Adji (2007) sudah melakukan penelitian untuk meningkatkan kemampuan berbicara siswa melalui permainan ular tangga yang dimodifikasi dengan lebih lengkap. Somantri (2003) menggunakan permainan bahasa- Thematic Simulation, dimana dia merancang permainan dengan menggunakan tema-tema seperti pasar, transportasi, rumah sakit, dan sebagainya. Dia mengatakan bahwa games ini sangat menyenangkan, mengubah iklim kelas menjadi menyenangkan dan dapat meningkatkan speaking dan writing skill siswa.

Sedangkan Jafrizal (2003) melaksanakan penelitian tindakan kelas untuk meningkatkan kreativitas dan kemampuan bicara siswa melalui KWL(Know- What To Know-Learning)dan language game.Teknik ini secara signifikan dapat meningkatkan kemampuan bahasa Inggris dan kepercayaan diri siswa. Sasmedi (2008) pun telah melakukan penelitian yang bertujuan meningkatkan kemampuan speaking siswa dengan menggunakan gambargambar secara berpasangan, yakni salah satu language games.Hasil penelitian ini menunjukkan bahwa penggunaan permainan ini dapat emningkatkan motivasi siswa dalam berbicara bahasa Inggris.

Peneliti bersama pengamat mendiskusikan tentang perkembangan kemampuan berbicara siswa mulai dari sebelum pelaksanaan tindakan hingga siklus terakhir. Dari data tersebut peneliti menemukan peningkatan yang signifikan. Ada lima aspek yang diamati dalam speaking skill, yaitu utterances,fluency, structure,vocabulary dan understanding yang dapat dilihat pada tabel berikut:

Tabel 4 Perbandingan Speaking Skill Siswa

\begin{tabular}{|c|c|c|c|c|c|}
\hline \multirow[t]{2}{*}{ Waktu } & \multicolumn{5}{|c|}{ Skor Rata-rata Speaking Skill } \\
\hline & Utterance & Fluency & Structure & Vocabulary & Understanding \\
\hline Sebelum PTK & & & 1, & & \\
\hline Siklus 1 & & & 1, & & \\
\hline Siklus 2 & & & 2 , & & \\
\hline Siklus 3 & & & 3, & & \\
\hline
\end{tabular}

\section{Motivasi Belajar}

Untuk mengobservasi motivasi belajar siswa, peneliti merancang sebuah rubrik skor yang dapat mengakses motivasi belajar siswa tersebut. Indikator-indikator yang dimuat di dalamnya terdiri dari indikator working, competition, curiosity, danmoodcondition. Berdasarkan hasil penelitian yang telah dijabarkan sebelumnya, dapat kita bandingkan sebagai berikut:

Tabel 5 Perbandingan Motivasi Belajar Siswa

\begin{tabular}{ccccc}
\hline Waktu & \multicolumn{4}{c}{ Skor Rata-rata Indikator Motivasi Belajar } \\
\cline { 2 - 5 } & Working & Competition & Curiousity & Mood Condition \\
Sebelum PTK & 2,2 & 2,7 & 3,2 & 3,5 \\
Siklus 1 & 2,7 & 2,7 & 3,1 & 3,5 \\
Siklus 2 & 3,2 & 2,7 & 3,1 & 3,4 \\
Siklus 3 & 3,5 & 2,6 & 3,3 & 3,5 \\
\hline
\end{tabular}




\section{SIMPULAN DAN SARAN}

Berdasarkan hasil penelitian dan pembahasan, ada beberapa hal yang dapat disimpulkan. Pertama, terdapat peningkatan speaking skill siswa setelah penerapan pembelajaran dengan English Games. Kedua, terdapat pula peningkatan motivasi belajar siswa setelah penerapan pembelajaran dengan English Games. Ketiga, selain penerapan pembelajaran dengan English Games, disinyalir juga terdapat faktor-faktor lain yang mendorong meningkatnya speaking skill dan motivasi siswa, yaitu guru, kondisi siswa, waktu dan tempat belajar, serta topik pembelajaran.

Berikut adalah beberapa saran terkait penelitian ini. Pertama, guru English di sekolah kejuruan hendaknya menerapkan pembelajaran dengan English Games ini jika menemukan bahwa siswanya lemah dalam speaking skill dan motivasi. Kedua, peneliti sebaiknya lebih kreatif dan penuh persiapan sebelum melaksanakan pembelajaran sehingga siswa pun menjadi lebih termotivasi. Ketiga, peneliti sebaiknya benar-benar memahami tentang English Games sebelum mempraktikannya.

\section{DAFTAR RUJUKAN}

Azhar, Arsyad. (2006). Media Pembelajaran. Jakarta: Raja Grafindo Persada.

Ahmad, Rohani. (1997). Media Intruksional Edukatif. Jakarta: Rineka Cipta

Arief,Sadiman S.dkk. (2008). Media Pendidikan. Jakarta: Raja Grafindo Persada.

Sudjana, Nana. (2005). Media Pengajaran. Bandung: Sinar Baru Algensindo.

Oemar, Hamalik. (2008). Proses Belajar Mengajar. Jakarta: Bumi Aksara.

Wibawa,Basuki. (1991). Media Pengajaran. Jakarta: Depdikbud.

Mujadi. (1995). Materi Pokok Desain dan Alat Peraga. Jakarta: Dirjen Pendidikan Dasar dan Menengah. 